\title{
Quantitative Determination of Metallic Iron Content in Steel-Making Slag
}

\author{
Zhiyong Xu, Jim Hwang, Robert Greenlund, Xiaodi Huang, \\ Jinjing Luo, and Steve Anschuetz \\ Institute of Materials Processing \\ Michigan Technological University \\ 1400 Townsend Drive \\ Houghton, MI 49931 \\ USA
}

\begin{abstract}
A quantitative analytical method for metallic iron was developed for wastes from iron and steel mills. These wastes consist of slags, dusts and sludges, mill scales, spent pickle liquor, and other iron-bearing materials. Accurate determination of metallic iron in these wastes will provide the vital information for the recycling or reuse of these wastes. The new procedure for the determination of metallic iron $\left(\mathrm{Fe}^{0}\right)$ was developed and various factors that could affect the test result were determined. Pure metallic iron powders were mixed with pure iron oxides with various ratios and then were tested using this method. Testing results had excellent agreement with actual concentration. Samples from several sites have been tested.
\end{abstract}

Keywords: metallic iron, analysis, steel slag, recycling.

\section{Introduction}

The steel industry in the United States generates large tons of by-products each year. The majority of these by-products are present in various forms of slag, sludge, and dusts. The recycling of these by-products has made significant progress in the past years. These by-products provide significant iron units and other value when recycled and properly reused [1]. However, a large amount of these by-products have been stockpiled at steel mills or have been discarded in landfills at a high cost.

Michigan Technological University (MTU), with steel industry partners, has launched a project to fully utilize steel mill by-products to generate revenues, conserve energy, and alleviate environmental problems caused by these by-products. One of goals of this project is to increase the efficiency of iron unit recovery from by-products. To recover the iron units efficiently, fine grinding is necessary for liberation. Traditionally, this approach has been avoided because conventional separation techniques using magnetic separation is not an effective tool for processing fine dry materials. In addition, the non-magnetic, non-iron bearing slag fines do not have an existing market demand and the disposal of the fines can be a problem. To overcome these obstacles, a process 
technology utilizing air classification has been developed at the Institute of Materials Processing, MTU, which can effectively separate the metallics and iron oxides at particle sizes that are finer than that of convectional dry magnetic separation technology. The technology can create higher separation efficiency, thus creating significant gains in iron unit recovery.

Because of increased selectivity expected from the iron recovery process, high grade products on the order of $90 \% \mathrm{Fe}$ will be generated, briquetted, and fed to BOF (basic oxygen furnace) or EAF (electric arc furnace) operations. Also lower grade products similar to iron ore pellet quality $(60 \% \mathrm{Fe})$ will be generated. This product will be pelletized or briquetted for BF (blast furnace) feed. Both products offer a quick iron return to the mill.

The accurate determination of metallic iron content and total iron content is vital before and after processing of the received by-products. This is critical for the mass balance, results interpretation, and quality control. There are several well-defined methods for the determination of the total iron content in iron ores and related materials. These methods include silver reduction-dichromate titration (ASTM E 1081-95a) [2], hydrogen sulfide reduction and dichromate titration (ASTM E 246-95) [3], and dichromate titrimetry (ASTM E 1028-98) [4]. However, no ASTM standard test method of metallic iron content for iron or steel slags and related materials has been defined. When the slag sample is sent to the different labs, the different and even contradicted results are given. It is very difficult to make a decision how to deal with the steel-making by-products without an accurate metallic iron content measurement.

There are a few approaches to test the metallic iron content. The Kentucky transportation cabinet issues a method to cover the determination of particles (by mass) containing iron in blast furnace slag [5]. This method applies a magnet to collect the metallic iron particles. Obviously, this method only provides the approximate result, due to the metallic particles often being imbedded in non-metallic particles for the ironmaking or steel-making slags. Another method uses mercuric chloride to extract metallic iron from slag [6]. However, a protective film is formed on the surface of metallic iron to prevent further dissolution. This method usually gives lower metallic iron value than the true value.

The basis of the metallic iron determination method in this study is the following chemical reaction:

$$
\mathrm{Fe}+\mathrm{CuSO}_{4} \rightarrow \mathrm{FeSO}_{4}+\mathrm{Cu}
$$

Solid metallic iron replaces the $\mathrm{Cu}^{2+}$ in the solution and becomes $\mathrm{Fe}^{2+}$. Solid metallic iron content can be determined by determining the $\mathrm{Fe}^{2+}$ content in the solution.

The objective of this study is to develop an accurate method to determine the metallic iron content in the steel-making by-products, whereby this method can also be 
used for the determination of metallic iron content for direct reduced iron and related materials.

\section{Experimental}

\section{Sample Preparation for analytical samples}

- The test sample shall be repetitively pulverized or ground and screened at 65 mesh to the point where confidence exists that the +65 fraction is $100 \%$ metallic in nature. The -65 mesh portion will be tested in the following procedure.

\section{Metallic Iron Determination Procedures}

- Weigh 0.5 gram sample and put it into a beaker

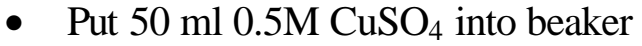

- Put $50 \mathrm{ml}$ distilled water into beaker

- Put beaker on hot plate and let boil for 45-60 minutes (covered with watch glass), stir with glass bar in order to prevent powder sample from agglomerating, and add distilled water as necessary to keep solution a constant level in the beaker.

- Filter into $250 \mathrm{ml}$ flask right after boiling, dilute the solution to $200 \mathrm{ml}$ or so with distilled water, and then add $\mathrm{HCl}$ to adjust the $\mathrm{pH}$ value of the solution to equal or less than 1.

- Add the distilled water to $250 \mathrm{ml}$

- Determine the metallic iron content by ICP.

Five synthetic samples, mixing the pure metallic iron powder and iron oxide powder (a mixture of $\mathrm{FeO}$ and $\mathrm{Fe}_{2} \mathrm{O}_{3}$ ), were tested to verify the test method. Six slag samples from the different sites have also been tested.

\section{Results and Discussion}

Table 1. Test results for five synthetic samples

\begin{tabular}{|c|c|c|c|c|}
\hline Test & $\begin{array}{c}\text { Metallic Iron } \\
\text { Powder }\end{array}$ & $\begin{array}{c}\mathrm{FeO} \text { and } \mathrm{Fe}_{2} \mathrm{O}_{3} \\
\text { Powder }\end{array}$ & $\begin{array}{c}\text { Measured } \\
\text { Metallic Iron }\end{array}$ & Error \\
\hline 1 & $100 \%$ & 0 & $99.09 \%$ & $0.91 \%$ \\
\hline 2 & $80 \%$ & $20 \%$ & $80.04 \%$ & $0.04 \%$ \\
\hline 3 & $40 \%$ & $60 \%$ & $40.94 \%$ & $0.94 \%$ \\
\hline 4 & $20 \%$ & $80 \%$ & $20.51 \%$ & $0.51 \%$ \\
\hline 5 & 0 & 100 & $0.11 \%$ & $0.11 \%$ \\
\hline
\end{tabular}

The results given in Table 1 demonstrate the overall error for metallic iron analyses is less than $1 \%$. 
Table 2. Iron Analyses for six Slag Samples from Different Sites

\begin{tabular}{|c|c|c|c|c|c|c|}
\hline \multicolumn{6}{|c|}{ Total Iron and Metallic Iron Concentrations of Slag Samples (wt. \% ) } \\
\hline Samples & Slag 1 & Slag 2 & Slag 3 & Slag 4 & Slag 5 & Slag 6 \\
\hline Total Fe & $55.47 \%$ & 28.03 & 41.88 & 17.27 & 23.89 & 22.51 \\
\hline Metallic Fe & 28.09 & 4.84 & 37.88 & 3.03 & 3.19 & 5.63 \\
\hline
\end{tabular}

The results given in Table 2 indicate different steel slags have different iron units and different metallic iron contents. Accurate measurement of metallic iron content provides a key parameter for reusing and recycling of the steel slag.

The method to analyze the metallic iron in this project is relatively easy. However, there are several factors to affect accurate test results. The main factors include sample preparation, sample handling, and $\mathrm{pH}$ values.

First of all, the slag samples have to be ground to pass 65-mesh (-65 mesh) and to liberate the metallic iron out. When the slag particle is too big, the metallic iron may still be covered by the non-metal materials and cannot have contact with $\mathrm{Cu}^{2+}$, which will cause analytical error. It is difficult to grind the metallic iron part of the slag, and some part of metallic irons cannot pass 65 -mesh ( +65 mesh). Combining the test results of two parts (-65-mesh and +65 -mesh) on a weighted percentage basis will give the total metallic iron for the slag sample.

Continuous stirring of the testing solution is also very important for obtaining accurate results, because no stirring will lead the $\mathrm{Cu}$ precipitates to form a $\mathrm{Cu}$ thin film around the metallic iron particles and prevent $\mathrm{Cu}^{2+}$ from further attacking the inside of the metallic iron particle.

The $\mathrm{pH}$ value of the testing solution is another key factor for the metallic iron analysis. When boiling the slag sample in $0.5 \mathrm{M} \mathrm{CuSO}_{4}$ solution, the $\mathrm{pH}$ value should be around 7. If the $\mathrm{CuSO}_{4}$ solution $\mathrm{pH}$ value is too high, the iron oxide will partially dissolve into the solution, which will interfere with the metallic iron concentration and exaggerate the metallic iron content in the slag.

After boiling the slag sample, the solution should be filtered immediately. When the solution temperature begins to decrease, the $\mathrm{Fe}^{2+}$ and $\mathrm{Fe}^{3+}$ will partially precipitate to form $\mathrm{Fe}(\mathrm{OH})_{2}$ and $\mathrm{Fe}(\mathrm{OH})_{3}$, especially for the high metallic iron content slag. The $\mathrm{pH}$ value of the filtrate should be adjusted to 1 in order to avoid the precipitation of $\mathrm{Fe}(\mathrm{OH})_{2}$ and $\mathrm{Fe}(\mathrm{OH})_{3}$. When the concentration of iron in the filtrate is high, a brown precipitate is observed from the solution right after filtering if no adjusting of the $\mathrm{pH}$ value takes place. The $\mathrm{pH}$ value and temperature determine the solubility of $\mathrm{Fe}(\mathrm{OH})_{2}$ and $\mathrm{Fe}(\mathrm{OH})_{3}$.

One factor that needs to be considered is the oxidation of $\mathrm{Fe}^{2+}$ to $\mathrm{Fe}^{3+}$ in water. If oxygen is present, some of the $\mathrm{Fe}$ (II) oxidizes to $\mathrm{Fe}$ (III).

$$
\mathrm{Fe}^{2+}+\mathrm{H}^{+}+0.25 \mathrm{O}_{2}=\mathrm{Fe}^{3+}+0.5 \mathrm{H}_{2} \mathrm{O} \text {. }
$$


The time for complete oxidation of $\mathrm{Fe}^{2+}$ is a matter of minutes in an aerated solution when $\mathrm{pH}$ is above 7.0. The rate of oxidation of $\mathrm{Fe}^{2+}$ by $\mathrm{O}^{2}$ in water is given by Singer and Stumm[7].

The following are the solubility equilibriums of $\mathrm{Fe}(\mathrm{OH})_{2}$ and $\mathrm{Fe}(\mathrm{OH})_{3}$, respectively:

$$
\begin{gathered}
\mathrm{Fe}(\mathrm{OH})_{2(\mathrm{~s})}=\mathrm{Fe}^{2+}{ }_{(\mathrm{aq})}+2 \mathrm{OH}_{(\mathrm{aq})}^{-}, \mathrm{K}_{\mathrm{sp}}=\left[\mathrm{Fe}^{2+}\right]\left[\mathrm{OH}^{-}\right]^{2}=4.87 \times 10^{-17} \text {, and } \\
\mathrm{Fe}(\mathrm{OH})_{3(\mathrm{~s})}=\mathrm{Fe}^{3+}{ }_{(\mathrm{aq})}+3 \mathrm{OH}^{-}{ }_{(\mathrm{aq})}, \mathrm{K}_{\mathrm{sp}}=\left[\mathrm{Fe}^{3+}\right]\left[\mathrm{OH}^{-}\right]^{3}=2.79 \times 10^{-39}
\end{gathered}
$$

$\mathrm{K}_{\mathrm{sp}}$ is the solubility product constant [8].

Because the $\mathrm{K}_{\mathrm{sp}}$ for $\mathrm{Fe}(\mathrm{OH})_{3}$ is much smaller than that of $\mathrm{Fe}(\mathrm{OH})_{2}$, it is only necessary to find the maximum $\mathrm{pH}$ value of the filtrate to prevent $\mathrm{Fe}(\mathrm{OH})_{3}$ from forming a precipitate. Since $\mathrm{K}_{\mathrm{sp}}$ is so small, the $\left[\mathrm{OH}^{-}\right]$from the $\mathrm{Fe}(\mathrm{OH})_{3}$ dissolution is negligible compared to the $\left[\mathrm{OH}^{-}\right]$from the dissociation of water.

$$
\begin{gathered}
\mathrm{K}_{\mathrm{sp}}=\left[\mathrm{Fe}^{3+}\right]\left[\mathrm{OH}^{-}\right]^{3}=2.79 \times 10^{-39} \\
{\left[\mathrm{Fe}^{3+}\right]=2.79 \times 10^{-39} /\left[\mathrm{OH}^{-}\right]^{3}}
\end{gathered}
$$

In order to prevent precipitate generation for different $\mathrm{Fe}^{3+}$ concentrations, the required maximum $\mathrm{pH}$ values are given in Table 3. For example, when $\mathrm{pH}=2$, the maximum $\mathrm{Fe}^{3+}$ concentration is 156 ppm:

$$
\left[\mathrm{Fe}^{3+}\right]=\left(2.79 \times 10^{-3} \mathrm{M}\right)(55.845 \mathrm{~g} / \mathrm{mol})=0.156 \mathrm{~g} / \mathrm{L}=1.56 \times 10^{2} \mathrm{ppm}(\mu \mathrm{g} / \mathrm{ml})
$$

Table 3. The maximum $\mathrm{pH}$ values needed for the different $\mathrm{Fe}^{3+}$ concentrations.

\begin{tabular}{|c|c|c|c|}
\hline $\mathrm{pH}$ value & {$\left[\mathrm{OH}^{-}\right]$} & {$\left[\mathrm{Fe}^{3+}\right](\mathrm{M})$} & {$\left[\mathrm{Fe}^{3+}\right](\mathrm{ppm})$} \\
\hline 1 & $1 \times 10^{-13}$ & 2.79 & $1.56 \times 10^{5}$ \\
\hline 2 & $1 \times 10^{-12}$ & $2.79 \times 10^{-3}$ & $1.56 \times 10^{2}$ \\
\hline 3 & $1 \times 10^{-11}$ & $2.79 \times 10^{-6}$ & $1.56 \times 10^{-1}$ \\
\hline 4 & $1 \times 10^{-10}$ & $2.79 \times 10^{-9}$ & $1.56 \times 10^{-4}$ \\
\hline 5 & $1 \times 10^{-9}$ & $2.79 \times 10^{-12}$ & $1.56 \times 10^{-7}$ \\
\hline 6 & $1 \times 10^{-8}$ & $2.79 \times 10^{-15}$ & $1.56 \times 10^{-10}$ \\
\hline 7 & $1 \times 10^{-7}$ & $2.79 \times 10^{-18}$ & $1.56 \times 10^{-13}$ \\
\hline
\end{tabular}

Usually, the concentration of 0.5 gram pure metallic iron (100\% iron) in the 250 $\mathrm{ml}$ solution is $2000 \mathrm{ppm}$. So, the $\mathrm{pH}$ value for the test solution should be less than 2 . 


\section{Acknowledgements}

The authors gratefully acknowledge the Department of Energy for providing financial support to the research program, Recycling \& Reuse of Steel Mill By-products, Phase I: Verification of Iron Contents, at Michigan Technology University.

\section{Reference}

1. Steel Industry Technology Roadmap, December, (2001).

2. ASTM, Standard Test Method for Determination of Total Iron in Iron Ores and Related Materials by Silver Reduction-Dichromate Titration, ASTM E 1081-95a, Annual Book of ASTM Standards, Vol. 03.06, 311-314 (2000).

3. ASTM, Standard Test Method for Iron in Iron Ores and Related Materials by Hydrogen Sulfide Reduction and Dichromate Titration, ASTM E 246-95, Annual Book of ASTM Standards, Vol. 03.05, 249-252 (2000).

4. ASTM, Standard Test Method for Total Iron in Iron Ores and Related Materials by Dichromate Titrimetry, ASTM E 1028-98, Annual Book of ASTM Standards, Vol. 03.06, 292-295 (2000).

5. Kentucky Transportation Cabinet, KM 64-618-01 Metallic iron content in slag, (2001).

6. J. Aubry and P. Perrot, Chim. Anal., 47, No. 4, 177-179 (1965).

7. P. C. Singer and W. Stumm, Acid mine drainage-the rate limiting step, Science, v. 167, 1121-1123 (1970).

8. David R. Lide (Editor-in-Chief), CRC Handbook of Chemistry and Physics, $80^{\text {th }}$ Edition, (1999-2000). 